[The following text is the version published, post-peer review, in 6 Social and Legal Studies (1997) 553-572. For the

definitive version, see

http://sls.sagepub.com/content/6/4/553.full]

Sodomites in the Pillory in Eighteenth-Century London

by Peter Bartlett*

The arrival of the eighteenth century brought with it new legal attention to sodomitical behaviour. Nowhere was this more notorious and public than in the punishment of those offences in the pillory. This paper argues that the pillory was a productive space for the understanding of sodomy in this period, a place where the logic and practice of that particular punishment intersected with a new and emerging conceptualization of masculinity and erotic desire between men.

The intersection between these discourses had a dynamic function: far from merely reflecting public attitudes prevalent elsewhere, the practices of the pillory helped to create the new attitudinal structure to sodomitical behaviour.

Introduction

It seems clear that by roughly the end of the seventeenth century, a distinctively sodomite subculture had established

*Address for correspondence: Department of Law, University of Nottingham, Nottingham, NG7 2RD. Earlier versions of this paper were presented to the Queer Legal Studies conference at Lancaster in September 1995, the annual conference of the [American] Law and Society Association in Glasgow, July 1996, and the Lesbian and Gay History Discussion Group, Department of History, University of Toronto, October 1996. My thanks to Mary Coombs, Douglas Hay, Richard Ireland, Dianne Martin, Leslie Moran, Roy Porter and Alan Yoshioka for their comments on earlier drafts of this work. Errors of course remain my responsibility. My thanks also to Dr. J. Drysdale, for sharing the tedium of locating sodomy-related cases in the old Bailey Sessions Papers. 
itself in London. [McIntosh (1968), Bray (1982), Trumbach (1976, 1985, 1989, 1990), Norton (1992), Simpson (1984)] ${ }^{i}$ Along with it, and affecting those of sodomitical tendencies outside the subculture, came a new articulation of masculinity and gender relations. The increasing urbanization in London was leading at least in the working classes to a shift from power relations defined by relations of kinship, to new social roles defined by gender. In the view of these scholars, the eighteenth century involved the introduction of a new masculine code, and the re-characterization of sodomitical activity was one of the ways in which the male role was formulated. Sodomy previously, when a matter of concern at all, had been viewed in the context of religous heresy, and by English Protestants as a particularly Catholic abomination. [Greenberg (1988)] Such associations did not die, but were overlaid with a new, gendered understanding. Masculine virtue became articulated in opposition to same-sex erotic desire. As those gendered logics became more significant in the eighteenth century, sodomitical practices came to occupy a new centrality in the understanding of deviance, and to take on a particularly socially threatening aspect.

The development of the new ideology of sodomy was not exclusively based in re-understanding of gender, but also on the practical possibilities presented by London social life. Whether based in a less prurient society under the restoration [Greenberg (1988), 326], economic change flowing from industrial change [Weeks (1981)], the relatively high marriage age for men as encouraging non-marital sexual relations, or the urban context of London which allowed for anonymity of individuals [Bray (1982)], it seems clear that there were the foundations for a sodomitical subculture in London by the end of the seventeenth century, a subculture which continued throughout the succeeding century. The clearest manifestation of this subculture may be found in molly houses of the eighteenth century, the collection of pubs and quasi-private 
parties which catered to persons with sodomitical interests. The legal records and the popular press of the eighteenth century described in voyeuristic terms the rituals of crossdressing, sexual banter, sexual play of these institutions. The sensationalism of many of these accounts suggests that they should not be taken entirely uncritically, yet as Greenberg points out, their relative consistency suggests equally that they should not be entirely discounted. [Greenberg (1988) 333]

The molly houses present the clearest example of sodomitical subculture, as distinct from mere sodomitical activity, since they appear to have created some form of identity among their patrons. Other loci of sodomitical activity are more ambiguous. There would certainly appear to have been a network of cruising groundsii throughout the century, well known and active; but the self-perceptions of its frequenters are more difficult to judge. This problem is compounded as the sexual activity is moved outside the institutional context. The eighteenth-century old Bailey trials include numerous instances of sodomitical activity which on their face appear to be outside the realm of subculture, reflecting instead the structures of eighteenth-century life. A variety of cases, for example, involved activity between apprentices and others living in the master's household. [see, eg., Pryor OBSP Dec. 1742; Laurence OBSP Aug. 1730; Malcolme OBSP July 1726]. It is not obvious that the accused in such cases would have understood himself in subcultural terms. When William Brown was entrapped in a cruising area in Moorfields in 1726, he said to the watch "I think there's no crime in making what use I please of my own body." [OBSP, July 1726]. This has been read as a defiant statement, marking Brown's claim over his own body. [Bray (1982) 114]. Certainly that is a possible reading, but the statement may also be read as reflecting an innocence (perhaps feigned in this case, in hopes of release with a warning) that the law would concern itself 
with a minor sexual encounter between men. Such a reading would be reminiscent of the pedophile in the introductory volume of Foucault's History of Sexuality, who may not have understood his behaviour in terms of legal regulation. [Foucault (1978) 31-2] Such a reading would suggest a shift over the course of the eighteenth century. Legal structures, including the scaffold and, most significant for this essay, the pillory, publicized the legal attention to and construction of sexual relations between men to a degree that Brown's supposed innocence, if that is what it was, would be untenable by the end of the century.

If the core of the sodomitical subculture was thus established by the end of the seventeenth century, the development of a new masculine identity was slower to evolve. Simpson associates its genesis with the change from skilled to unskilled work:

In particular, the traditional role of the father, in directing and guiding his son by working with him and teaching him work and life skills, was made redundant. Fathers no longer had an important part in helping their sons to acquire needed skills, and could therefore no longer command their respect by that means. All the father had to offer was the personal image of a hardness that had no parallel elsewhere in the family, or outside of the world of men. [Simpson (1984) 619]

Yet this transition was a gradual process, and as simpson himself acknowledges, was by no means complete by the end of the eighteenth century. [Simpson (1984) 636] Similarly, dividing lines between employment appropriate for men as opposed to women were developed over the course of the eighteenth century. [Hill (1989)] While these distinctions were eventually reflected in different grass-roots political 
structures between men and women, these were not in place at the beginning of the century, but rather developed over time. [Bohstedt (1988)]

Bray, Trumbach, Greenberg and Simpson all place considerable stock in the legal records of the period in support of their arguments, but in their work the legal structures are peculiarly passive: the law mirrors or occasionally interferes or complicates, but does not of itself have a constitutive role in the articulation of the new understanding of sodomy. Les Moran by comparison has identified the generative potential of statute and common law in articulating the nature of sodomy. [Moran (1996)] This paper extends that argument into the most public realm of eighteenth-century law, punishment. Law and punishment are generative spaces, spaces which transform, rather than merely reflect. The particular study here concerns the punishment of the pillory for those convicted of sodomitical behaviour, and the way in which the practices and dynamics of the pillory affected the understanding of sodomy and sodomites in the eighteenth century.

\section{'Sodomy' and the Law}

The pillorying of sodomites is a particularly interesting locus for consideration of the interplay between law and other cultural factors for several reasons. On questions of substance, this was not an area where the law was hide-bound by tradition. Sodomy itself had been a capital offence since the time of Henry VIII. During the reformation, Henry had secularized numerous ancient ecclesiastical felonies, and sodomy thus became a capital crime subject to prosecution in the common law courts in 1533. [25 Hen. 8 c. 6] It was returned to ecclesiastical control under Mary I, before being restored permanently to the civil courts under Elizabeth in 1563. [5 Eliz. c. 17] When sodomy became a felony, its attempt 
became a misdemeanour. Few attempt cases were brought prior to 1700, but in the eighteenth century, it was certainly a known offence, and it was for this, along with assault with intent to commit sodomy, that offenders were sentenced to a term in the pillory.

Notwithstanding the legislative consistency, the eighteenth century law did not simply mirror its earlier self. Late mediaeval and early modern law of sodomy hac been contextualized in terms of religous decadence. [Greenberg (1988)] With the English reformation, this was related particularly to Roman Catholicism. Sodomitical behaviour has never entirely last those associations in the popular imagination, but by the eighteenth century, the legal logic had shed much of its religous and Roman Catholic focus. Sodomy became understood more directly as involving regulation of male sexuality. The gendering of the law in this regard is not without its ambiguities. In 1718, the King's Bench did hold that sodomy of a woman by a man was within the scope of the statute, [R. V. Wiseman (1718) Fort. 91] but this is an anomaly. No cases of sodomy or attempt sodomy at the eighteenth-century old Bailey involved such facts. The Middlesex sessions did see two instances. In the first, alleging the accused buggered his wife, a not guilty verdict was reached. [Bishop, GLRO X71/11, June 1746] In the second, for reasons not recorded, the indictment was found to be ignoramus, terminating the proceedings prior to evidence being called. [Wilford, GLRO X71/14, Jan. 1772] Instead, when a man was alleged to have engaged in anal intercourse with a female child in 1750, the charge at the Old Bailey was rape. [OBSP, July 1750] Bestiality cases were similarly rare. ${ }^{i i}$ Sodomitical charges in practice involved two men.

Notwithstanding some earlier dispute, by the eighteenth century the elements of the felony required proof both of penetration and emission. ${ }^{\text {iv }}$ The misdemeanour charges did not 
have the clearly defined context of proof of the felony. They did not necessarily refer to "attempts" in the modern sense. Certainly, there were cases where the participants were caught in situations where it would be reasonable to surmise that but for interruption, the accused would have committed the full felony, but this by no means accounts for all of the convictions for the misdemeanour. John Painter and John Green were convicted in 1727, when they were found by a watchman merely in each others arms, and naked from the waist down. [OBSP, September 1727]. Julius Taylor was convicted in 1728 for sitting on the lap of John Burgess, and committing "indecent and effeminate Actions". [OBSP, October 1728] The misdemeanour was thus a flexible offence, not well defined, embracing a wide variety of activity between men.

The articulation of this broader offence in the eighteenth century fits well with the chronology of the increasingly restrictive attitude of the new masculinity to male sexuality in the period. In a search of the Old Bailey Sessions Papers for the final quarter of the seventeenth century, there appear to have been no attempt charges (and indeed no sodomy charges) prior to 1698. By the first decade of the eighteenth century, a sufficient trickle of such attempt charges existed to suggest that it had become a known offence in at least the legal consciousness.

\section{The spectacle of the Pillory}

A term in the pillory was usual for those convicted of sodomitical misdemeanours. Of twenty persons convicted at the Old Bailey between 1720 and 1750, fourteen were sentenced to at least one term in the pillory. " These are relevant in assessing the developing public perceptions, for the pillory was a peculiarly democratic punishment in the eighteenth century . Such had not always been the case. The origins of the pillory are rooted in the logic Foucault describes as "the terror". It 
was not merely that the criminal was to be displayed before the crowd, but also that the display would strike fear into the hearts of the crowd. In the pillorying of persons convicted of sedicious libel or uttering forged documents in the seventeenth century, the prisoner's ears would be cut off before the crowd, his or her nose slit, and he or she would sometimes be branded. [see Forster (1656) 64; Anon. (1759)]. By the eighteenth century, things had changed. The terror as a strategy inflicted directly by the state had disappeared, and the sentence to stand in the pillory was now intended instead to be a punishment which worked by shaming the convict. The criminal was to be exposed to public ridicule.

Such was the theory. The practice was that the criminal might be exposed to a good deal else: mud, stones, offal, dead animals, eggs (both fresh and, more frequently, rotten) and other unsavoury material might be hurled along with the verbal abuse of the eighteenth-century mob. This gives rise to our modern imagery of the pillory, but it is an incomplete image only, for the eighteenth-century crowd could be unpredictable. Thus in June 1763, the Public Advertiser was able to report,

Yesterday three Men stood on the Pillory in Palace-yard, opposite Westminster-hall Door, with a Label over their Heads, signifying their Crime was wilful and corrupt Perjury. They were Evidences in a cause relating to the Right to an Estate in Leicestershire.

Two of them were Father and Son, and they stood on one Pillory; the other Person stood on another, which was a new one. One of the Men is upwards of 70 Years of Age, another upwards of 60 . Their well-looking Aspect, their grey Hairs, and their Tears, which flowed in great Abundance, drew such Compassion from the Populace, that they treated them with the greatest Lenity, and some Money was collected for them. [3 June 1763, 3b] 
The pillory might even be a victorious occasion, as in the case of Williams, in February 1765, convicted of publishing a libellous tract concerning government policy in scotland, recorded in the Gentleman's Magazine:

[Upon arrival] He was received by the acclamation of a prodigious concourse of people. Opposite to the pillory were erected four ladders with cords running from each other, on which were hung a Jack Boot, an axe, and a scotch bonnet. The latter, after remaining there some time, was burnt, and the top of the boot chopt off. During his standing also, a purple purse, ornamented with ribbons of an orange colour, was produced by a gentleman, who began a collection in favour of the culprit, by putting a guinea into it imself, after which, the purse being carried round, many contributed, to the amount, in the whole, as supposed, of about 200 guineas. Mr Williams, at going into the pillory, and getting out, bowed to the spectators. He held a sprig of laurel in his hand all the time. [35: 96]

The pillory was thus a peculiarly democratic punishment, in the literal sense: it was a place where the crowd exercised power, in a very direct way. It could be a space of public approval, or of sanctioned violence. If we have moved from terror as a means of social control, we have certainly not arrived at a minute control of the body by the state, or the Foucaultean "gentler" ways of punishment. Punishment in the pillory remained a public event, lacking the nuanced attempts to appropriate the convict's mind which became the feature of nineteenth-century penal theory. Instead, we see a new relationship between the convict, the state, and the public. The seventeenth-century pillory had been a morality play in 
which the spectators had been the audience. The eighteenth century gave rise to a new sort of theatre, a spectacle in which the public is not merely audience, but a key player. It is this active role of the public shich has led John Beattie to call the pillory the "paradigm of eighteenth-century penal practice." [Beatty (1985), 39] The place of the state is no longer directly to provide corporal punishment, but instead to provide the site.

The state could otherwise affect the course of punishment of course. As prosecutor in seditious libel proceedings, it would have a particular interest in ensuring that the event did not become a victory for the criminal, and it is a fair speculation that they would attempt behind the scenes to ensure the presence of a crowd hostile to the criminal. ${ }^{i}$ In Williams' case, it may be that his friends arrived first, and occupied the prime locations.

In other contexts, far from providing the mechanics of punishment, the eighteenth century state would often be required to intervene against the crowd to protect the convict, and to keep the situation from getting out of control. For most of the century, this involved merely the provision of state forces to control crowds. Considerable numbers of troops or hired security men might be employed to ensure that the offender would not die in the pillory. When Isaac Broderick was pilloried for attempted sodomy in 1730, for example, Fogg's Weekly Journal reported that he was protected from the crowd by a party of foot guards consisting of forty men, with a serjeant and corporal. [30 May] Such techniques might lack subtlety, and there are instances of spectators being killed by overzealous policing. [eg. Times 23 Nov 1786, 3b] At other times, however, the techniques were unable to keep control of the crowd, and a number of people died in the pillory. In that event a crime might be found to have been committed. Thus when sodomite Thomas Blair died as a result of the crowd in in 
Cheapside in 1743, a coroner's jury brought in a verdict of wilful murder by persons unknown, [London Evening Post, 15 February 1743] and in 1732, Edward Dalton and Richard Griffith were convicted of the murder of John Waller, a perjurer, in the pillory. [OBSP, September 1732] Nonetheless, within that boundary, the crowd was allowed by the state to have its way. Indeed, this locus of uncontrol by the state was to prove central to arguments for its abolition in the nineteenth century. [Smith (1996), 31-37]

\section{Sodomites in the Pillory}

As the Blair case indicates, the situation for sodomites would be unlikely to be pleasant. A flavour of the event may be gleaned from the following description of the pillorying of those associated with the swan in Vere street, a molly house, in 1810 :

Such was the degree of popular indignation excited against those wretches, and such the general eagerness to witness their punishment, that, by ten in the morning, the chief avenues from clerkenwell prison and Newgate to the place of punishment were crowded with people; and the multitude assembled in the Haymarket, and all its immediate vicinity, was so great as to render the streets impassible. All the windows and even the very roofs of the houses were crowded with persons of both sexes; and every coach, waggon hay-cart, dray, and other vehicles which blocked up great part of the street, were crowded with spectators.

The Sherriffs, attended by the two City Marshals, with an immense number of constables, accompanied the procession of the Prisoners from Newgate, whence they set out in the transport caravan, and proceeded 
through Fleet-street and the Strand; and the Prisoners were hooted and pelted the whole way by the populace. At one o'clock four of the culprits were fixed in the Pillory, erected for and accommodated to the occasion, with two additional wings, one being allotted for each criminal; and immediately a new torrent of popular vengeance poured upon them from all sides. They day being fine, the streets were dry and free from mud, the defect was speedily and amply supplied by the butchers of st. James's-market. Numerous escorts of whom constantly supplied the party of attack, chiefly consisting of women, with tubs of blood, garbage, and ordare from their slaughter-houses, and with this ammunition, plentifully diversified with dead cats, turnips, potatoes, addled eggs, and other missiles, the criminals were incessantly pelted to the last moment. [Times, 28 september 1810]

In this case the Times was able to report that no accident had occurred but others convicted of sodomitical offences, like Blair, were not so fortunate. Broderick claimed to have received permanent injury in the pillory. The coach returning a certain Mr. L [presumably John Lowther] to Newgate in 1761 was fallen upon by the crowd, and he apparently needed to be stowed in the compter [local gaol] for his protection. [Gentleman's Magazine, 31: 477.] The abuse of the crowds in 1726 was such that Margaret (or 'Mother') Clap, convicted of keeping a house for sodomites, apparently fainted twice in the pillory. Like Blair, Daniel Lobley died in the pillory, in 1763. It is thus not surprising that when cook was convicted of keeping a house for sodomites in 1810, he attempted to bargain by exposing sodomites not for a remission of his prison sentence or a reduction of his fine, but instead for a remission of his pillorying. [Holloway, (1813) 19] 
The scene at the pillory was thus almost a macabre carnival. Through its use, sodomites became visible, and an occasion was created for public interaction about sodomy. The repetition and discursive re-construction of these events in the public press became a further articulation and dissemination of attitudes to sodomitical behaviour. In part, the result reflected broader social conceptions regarding sodomy, but the spectacle remained a pillorying, and was equally confined by the social expectations and legal restrictions of that genre.

Sodomites, The Pillory and Gender

There is much in the accounts of the pillorying of sodomites to support the view that the discourses surrounding sodomitical behaviour in this period articulated a new masculinity. The account of the vere street pillorying above is not unusual in its reference to the "party of attack" as "consisting chiefly of women". ${ }^{\text {vii }}$ In another account of the Vere street pillorying, selected women were permitted a privileged position, closer to the criminals, than men, and they were apparently plied with drink to keep their strength up for the attack. [Gilbert (1977) 107] This was a common method of containment of the crowd's aggression used by the sherriff's officers whereby only women were permitted within a certain distance of the pillory. It was not restricted to sodomitical cases, [McLynn (1989) 283] but the accounts of the pilloryings of sodomites use this mechanism to re-enforce the new genderrelated articulation of sodomitical behaviour. Women are portrayed, not necessarily as placed near the pillory by a practice of crowd control, but instead as particularly aggrieved parties. In a ballad of 1726 concerning the pillorying of another sodomite, probably Thomas Dalton, a similar theme appears:

When to the Pillory he came, 
The Women gather'd all for Game

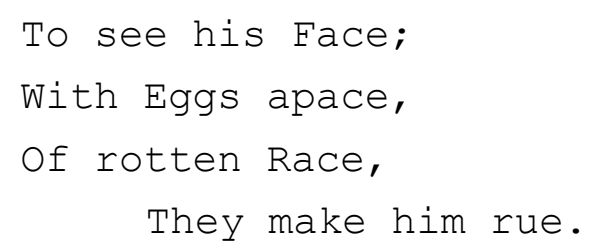

The Women down his Breeches took,

And underneath some gave a Look;

And those by Mars,

Did whip his A--e

For all his stars,

Ev'n in the street.

In this ballad, women are presented as the sole aggressors: men are written out of the narrative entirely. viii

These narratives are consistent with non-legal references to women as particularly aggrieved by sodomitical behaviour and its apparently increasing number of practitioners. The anonymous author of the 1760 pamphlet "Plain Reasons for the Growth of Sodomy in England" speaks of the soft and coddling education of boys producing creatures unfit to serve King, Country, or Family, specifically "unable to please the Women" and who are repulsive to any self-respecting woman in any event. In the ballad quoted above, the theme of betrayal of womankind is as clear. The subject, while in his cups, turns from his wife and goes out "drinking, swearing, sodomiting", and is whipped by the crowd in the pillory,

\author{
For leaving Women fine and gay \\ To make a monstrous sort of Play \\ With wicked Men \\ coiting when \\ More Brutal then \\ Than savage beast.
}


This theme may even be seen as entering the arena of the trial. Almost as a matter of routine, accused men would introduce evidence of their marriage as part of their defense. The case of Patrick Malcolme, charged with sodomy in 1726, is typical:

The Prisoner call'd several Men and Women to his Reputation, who depos'd that he was a kind Husband to his Wife, and a careful Father to his Children, and always preferr'd the Company of Women to that of the Men. -Many of his Male Bedfellows depos'd, that he had never offer'd such incivilities to them. [OBSP July 1726]

Similarly, it was counter-intuitive that women might be involved as facilitators of the offence. Margaret clap was charged with keeping a house for sodomites in 1726. In her defence she stated "that she was a Woman, and therefore it could not be thought that she would ever be concern'd to such abominable Practices." [OBSP, July 1726] .

This is not some sort of pre-curser of the Victorian image of the chaste or delicate woman, but rather reflecting a popular, gendered logic of the nature of eighteenth-century sodomy. The accounts of the pilloryings of sodomites instead tie in with the social construction of the crime itself. The sodomite places himself outside the realm of "natural" sexual relations. Less than a real man, whose worth in the new ideology is defined by sexual prowess, the sodomite is constructed as an affront and an insult to women; and it is women who, primarily, take their revenge in the pilloryings.

These are, of course, only accounts, and accounts written by men. They cannot be read uncritically as reflecting women's views of themselves. Women were active and aggressive in other forms of eighteenth-century rioting; [Bohstedt (1988)] there is 
no obvious reason they would not have been so active at the pillory. Nonetheless, they did not claim for themselves their relatively prominent position at the pillory. They were placed there, suggesting it may be unwise to rely too heavily on their behaviour as evidence of their own views of sodomy or new masculine conceptions of gender. The practices of the pillory are instead used in the accounts to re-enforce the emerging ideology of sodomitical behaviour.

\section{The Tolerant Society?}

Other aspects of the trials and pilloryings of attempted sodomites challenge the received history. Certainly, the pillory was a space where the crowd had considerable freedom of behaviour, and certainly the crowds were hostile to sodomites. At first blush, this suggests that the new sodomitical conception was relatively broadly accepted, even early in the century, yet there are other indicators which render the crowd hostility problematic. After all, there was a lot of sodomy around for much of the eighteenth century, which in society as a whole seemed to provoke remarkably little concern. At the end of the seventeenth century, rumours had been rife about William III and two of his generals, Bentinck and Wentworth. Lord Stanhope, who died in 1721, was notorious, but nonetheless had a successful army and political career. Lord Hervey, who died in 1743, lived openly with stephen Fox; yet this did not appear to hinder either particularly. Hervey became ViceChamberlain to George II. Another notorious sodomite, Lord George Germain (died 1785), ended his life as Secretary of State for America. ${ }^{\text {ix }}$

Certainly, one ought not generalize between the élite and the masses, but the records suggest restraint bordering on toleration by the public, until the matter enters the legal arena. To begin with, there simply weren't very many prosecutions related to sodomitical offences. Between 1715 and 
1799, I have found only seventy-two cases of sodomy-related charges (forty-two sodomy, thirty attempt or assault with intent) brought at the Old Bailey in London, resulting in thirty-eight convictions. Admittedly, particularly in the second half of the century, sodomy-related offences were also heard at Quarter Sessions at Hick's Hall and the Guildhall in London; yet the numbers from these sources also appear to have been very small.x

A couple of explanations for the small number of cases can be dismissed promptly. It is difficult to see that the small numbers are the result of difficulties of proof. The forty-two sodomy charges, which required proof of both penetration and emission, resulted in conviction about thirty-eight per cent of the time. As we have seen, the misdemeanour was much more flexible, and the conviction rate reflects that: seventy-three per cent of those tried for the misdemeanour at the old Bailey were convicted. Gilbert's figures for the beginning of the nineteenth century are even more convincing: a sixty-seven per cent conviction rate for the full felony, and an eighty per cent conviction rate for the misdemeanour between 1812 and 1818. This may be compared to thirty-three per cent for murder and twenty-three per cent for attempted murder in a similar period. [Gilbert (1978) 237]

It is similarly difficult to see that sodomites were difficult to find. Eighteenth-century cruising grounds appear to have been well-known by anyone who took the trouble to find out. [Trumbach (1976) 15, Harvey (1978) 944] If the prosecutions of the Society for the Reformation of Manners are to be believed, men were soliciting and engaging in sexual activity with each other not merely as today in the quasiprivate spaces behind bushes in parks, but on the public street. Prosecutions in 1707 organized by the society for the Reformation of Manners, for example, grew from indecent acts on London Bridge and the Royal Exchange. [OBSP October 1707, 
cases of Lane, Williams, Huggins, Marriot, Booth, Butler and Blithe] Activity in St. James Park appears to have been an open secret. There are also accounts of mollies being quite openly cross-dressed in the public street. John Cooper appears in the court record of 1732 because he unsuccessfully prosecuted an attempt by one Gordon to extort money from him with the threat of a charge of sodomy. According to defence witnesses, cooper chose to be known socially as the "Princess Seraphina". He apparently commonly dressed in a white gown, and delighted in attending masquerades and balls, always in women's clothes. [OBSP, July 1732, case of Gordon] Assuming this evidence is at all reliable, cooper cannot have been invisible; yet there is no suggestion that he had an encounter with the law other than his unfortunate prosecution of Gordon.

Other sources of the period suggest a similar laissezfaire attitude. On 13 June 1730, the month after Broderick's time in the pillory, Fogg's Weekly Journal noted that twenty Dutch sodomites had been recently been executed, and numerous others absconded. The following week, it noted that "some of the Sodomites who lately made their Escape from Holland, are safely arrived here" adding that "they have taken up their Quarters in a certain End of this virtuous Town, where they will hardly be able to corrupt their Neighbours." [20 June 1730, emphases in original]. Whether this is to be read as irony, humour, or resignation, the report contains no sense of outrage or condemnation.

The small number of cases is no doubt in part a reflection of the legal procedures for prosecution of offences in the eighteenth century. Prosecutions were private, and were cumbersome, time-consuming, expensive, or all three. ${ }^{x i}$ [Hay (1989) pp. 25-6, Phillips (1989) p. 116] Prosecution associations modified this system somewhat, but they were interested in property crime against their members, [Phillips (1989) p. 141; King (1989) p. 174] not sodomy-related activity. 
The Society for the Reformation of Manners in the first half of the century, and the society for the Suppression of Vice near the end of the century, did prosecute some sodomites, but this seems to be peripheral to their activities. Thus in 1730, more than half of the 754 prosecutions they claimed to have brought by the Society for the Reformation of Manners involved working on sunday. About one third involved lewdness or disorderly practices, including bawdy house offences, but the considerable bulk of these appear to have been related to heterosexual prostitution. The society prided itself on its suppression of sodomy, and its prosecutions occasionally resulted in highly visible convictions, as for example their half dozen or so molly house convictions in the late 1720s; but numbers were still small. Suppression of sodomites formed only a small part of its work. [Hare (1731), Wynn (1726)]

When the Society did prosecute sodomites, it seems to have had difficulty getting the cases into court. Thus it was claimed that the 1726 raid on Margaret Clap's molly house resulted in over forty arrests of sodomites; [OBSP July 1726, trial of Clap, evidence of Sellers] two trials, plus that of the keeper resulted. [OBSP April 1726 (trials of Lawrence, Griffin); OBSP July 1726 (trial of Clap)] The Society's view was that the Justices were unwilling to allow the charges to proceed. Francis Hare told the 1730 meeting of the society that these Justices "had neither Eyes nor Ears to see offences", wary of stirring up trouble, overly tender particularly to young offenders, and worried about a charge of hypocrisy, since "they are guilty, perhaps notoriously so, of the faults they ought to punish". [Hare (1731)]

The reluctance of Justices is consistent with Simpson's findings that of sixteen sodomy-related offences found in the records of the Guildhall Justice Room in the second half of the eighteenth century, only six were sent to the Grand Jury. [Simpson (1984) 455] Given the high conviction rates for 
sodomy-related offences noted above and the flexibility of the proof of sodomitical misdemeanours, it seems unconvincing to think that this behaviour was on legal grounds, suggesting an ambivalence of attitude to legal intervention into sodomitical behaviour. Certainly the law created a barrier to prosecution here, but that begs the question. Were the justices reflecting broader public ambivolence to sodomitical practices, or at least to the law's role in regulating such practices?

Regarding other morals charges, such as disorderly house charges, the law's intervention tended to be triggered by local community pressure, and the evidence suggests a similar attitude might prevail with sodomy-related charges as well. Thus for example when Richard spencer was charged with assault on William Taylor, an apprentice aged seventeen, with intent to commit sodomy, the constable would have been content to treat the matter informally. In Taylor's words,

The constable took hold of his arm, and ordered him to pay for what he had had [a reference to settling the bill in the alehouse where the event occurred]; the prisoner flung down three-pence, and the constable gave him a kick or two on the back side, and called him Black-guard old rascal, for making such an attempt on a boy, and turned him out of the house. I did not think he had punishment enough, ran after him, and with assistance brought him back again, and gave the constable charge of him, and he was committed. [OBSP, July 1749]

This account was confirmed by the constable in question, John Goodwin. Initially, Goodwin did not see the matter as a problem for the law. The arrest occurred only when Goodwin was pressured. There are various factors which would account for this ambivalence. In part, it was no doubt a response to the relatively trivial nature of the facts in the case. At issue 
was the prisoner making an indecent suggestion to Taylor, and exposing himself to him. In addition, there would have been problems of more general application. As in all criminal matters, the willingness and determination of the complainant to prosecute would figure high in the constable's assessment. credibility was a particularly serious issue in these cases, as the threat to lay a charge of sodomy was a common extortion technique, and the risk of wrongful convictions must have been a serious consideration.

At the pillory, there was no ambivalence. It must therefore be asked, to what extent the public anger was the result of the sodomitical aspects of the crime, and to what extent the result of the dynamics of the pillory itself, and, specifically, the nature and patterns of behaviour of the crowd which attended the pillory.

The Sodomite and the Dynamics of the Pillory

As Rudé, Thompson and others have shown in other contexts, the eighteenth-century crowd was not necessarily an irrational or haphazard body, but possessed a social and political space of its own, a moral economy, and a coherent structure. [Rudé (1964), Thompson (1971)] Similarly, coherent comments may be made of the crowd at the pillory.

The crowd at the pillory was composed of a mixture of classes. The mechanics of the event would be handled by the municipal officers, supported by such extra security as was thought to be needed. The Mayor or Justice might be present, in an ambiguous capacity as spectator and overseer, for he occasionally would intervene and stop the punishment early, if the prisoner was at risk. [see, eg., Times 26 september 1791] At Broderick's pillorying in 1730, a Justice and a member of the school governors were certainly present. While Broderick alleged they had a special interest in his punishment, there is 
no suggestion that their attendance appeared out of place. Particularly at pilloryings of libellists, references to gentlemen in the crowd pepper the reports. Further evidence of the mixture of classes are the fact that considerable sums might be taken up for those for whom the crowd had sympathy, and also that the pillory appears to have been a routine haunt of pickpockets. [Times 17 April 1788 3b, 17 August 1790 3c, 16 February 1796 3c.]

At the same time, the pillory must have catered increasingly to a crowd either local, or unemployed. The pilloryings did tend to occur at lunch time, and if the event occurred on a Monday, the bulk of the population did not work, and would have been able to attend in any event. Otherwise, hours of work appear to have become increasingly fixed over the course of the century. [v. Harrison (1986)] Working people local to the pillory would be able to attend, but otherwise, it would increasingly have been those who were out of work who would have the time to travel any distance for the event. Even for those not on fixed hours, the increasing pressure to produce more, for less money, would have created economic disincentives to taking the time to travel for a pillorying, unless the convicted person were of particular interest.

Some insight into the crowd is provided by a 1732 case in which Edward Dalton and Richard Griffith were convicted of murder arising from the death of John Waller, a perjurer, in the pillory. The evidence in that case states that both routinely attended pilloryings. Griffith had in fact once already been confined to Clerkenwell Bridewell as a result of his overly aggressive behaviour at the pillory. Both had been educated as children, and apprenticed, but had not remained in steady employment. While these two were presumably unusual-clearly not everyone who attended the pillory was a murderer-the unemployed and at least potentially rowdy were clearly one element of the pillory crowd. 
Notwithstanding the variety of crowd reactions to those in the pillory, it would seem that the default crowd at the pillory attended in expectation of an aggressive event. This image of a crowd expecting to abuse the convict is consistent with the report in Fogg's Weekly Journal in November 1728:

One Mitchel stood in the Pillory in Little Britain, for designing to extort Money from a Gentleman, by threatening to swear a detestable Sin against him-It was reported that he was to stand again in Aldersgate-street, upon which Occasion the Populace assembled, having furnish'd themselves with dead Cats, and other Ammunition used upon such Occasions; but the Person who was to make all the sport not appearing, they diverted themselves with throwing their dead Cats at one another. [9 November 1728]

The accounts make it difficult to distinguish whether the aggression meted out to sodomites was a function of the dynamics of the pillory, or the crowd's view of sodomy. Occasionally, there are hints which would suggest the former as a significant part of the account. Thus Gentleman's Magazine made the following report regarding the pillorying of George Butts and John Newarke for extortion by threatening a charge of sodomy in 1756:

These villains had the unparallel'd impudence before they mounted the pillory, to distribute several written papers reflecting on the honour of the gentlemen who prosecuted them, in order to obtain favour from the populace, but it had a contrary effect.' [26 (Mar 1756) 147]

Assuming the papers distributed alleged the truth of the charges Butts and Newarke intended to lay, it is interesting 
that they did not ellicit gentler treatment by the crowd, if the crowd were in other contexts motivated by an antisodomitical animus. As noted above, Gordon successfully used a similar sort of counter-attack on a similar charge laid by John "Princess Seraphina" Cooper. Similarly, when other those who successfully prosecuted their blackmailers were later uncovered as sodomites, polite opinion turned on them, in sympathy with the blackmailer. See for example remarks of the magistrate to Thomas Allison in 1828 [Anon (1828)], and regarding the Bishop of Clougher in 1822 [Anon (1822) at 13-4]. The failure of the technique at the pillory suggests a different set of factors at play .

If the default expectation was of an aggressive event, various techniques might be employed to sway the balance in favour of the convict. The criminal would encourage as many as possible of his friends to attend, to ensure a less violent treatment. Occasionally, the pillorying would be advertised by the criminal's friends, in attempt to turn the occasion into a political triumph. Thus a 1793 handbill proclaimed, "THIS DAY at TWELVE O'Clock, JOHN FROST is to STAND on the PILLORY at Charing Cross for supporting the RIGHTS of the PEOPLE !!!" And all spectators were not equal. While the bulk of the throng appears to have been of the relatively lower orders of society, they were sometimes swayed by the behaviour of the higher classes in attendance. Thus it was a gentleman, unnamed in the newspaper account quoted above, who began the collection at Williams' pillorying for libel in 1765, above. Occasionally by the end of the century, legal considerations might be relevant. The Times was able to report in 1786 regarding a perjurer named Lewis,

As soon as it was understood who the unfortunate man was, and that the lawyers in general deemed it rather a hard case, the congregation thinned rapidly, and departed in peace. [17 February 1786 3d] 
Sodomites, by comparison, were apparently unable to paper the house. It is not that they had no friends, for when cook was released from his prison term following his conviction of keeping a house for sodomites, he was able to round up funds from former patrons to defray some of his costs. While some of this may have been through threats of extortion, letters from John Church, a reformist minister and one of his more notorious patrons, would suggest that some patrons gave willingly. But these do not appear to have been the sort of friends who showed up for moral and practical support when one was exposed in the pillory. While the anger of the crowd may be in large measure a function of the dynamic of the pillory, not the understanding of sodomy, it was certainly not at a time when respectable opinion would challenge the criminalization of sodomitical behaviour. This is of course consistent with the approach adopted by Bentham: he favoured decriminalization, but did not do so publicly, as he considered the idea too radical for the times.

Parties openly friendly to the sodomite were not generally present, but aggrieved parties or the enemies of the convict might well be. Isaac Broderick, a schoolmaster pilloried for attempted sodomy in 1730, alleged that the charges had been trumped up by an unsympathetic school governor and Justice of the Peace. Both were present at the pillory. Broderick alleged that the crowd was in fact headed by the Justice, J, who "encouraged them, by his own Example, to assault and wound me." [Broderick (1731), 56] He later claims that the two not only encouraged the crowd, but "that their Injuries might pierce the deeper, hir'd a great Number of the Populace to assault and wound me, insomuch that I was almost cut to the skull, and tho' cur'd with much Difficulty, shall carry the Mark to my Grave." [Broderick (1731), 60]

The use of the pillory to settle old scores in this 
fashion seems not uncommon: Edward Dalton, noted above who was hanged for the murder in the pillory of the perjurer John Waller, was apparently motivated in part by Waller's involvement in the conviction of Dalton's brother for robbery, an offence for which the brother had been hanged the previous year.

In assessing the effects of the pillory, it is appropriate to distinguish the views of sodomites from the broader crowd watching and participating in the pillory event. Regarding the former, the events were public and notorious, and no doubt shaped the consciousness of actual and potential sodomites. The nature of the effect is open to some question. The pillory was intended as a mechanism publically to shame, and for sodomites, this appears to have been reflected in practice, at least for those such as the Cambridge-educated Isaac Broderick, who had a reputation to lose. And of course, much more direct was the physical threat of exposure in the pillory. Broderick's account of his own experience notes both these factors:

I must here beg leave to mention the general Treatment of those who stand in the Pillory. I presume, the design of the Law, in such Cases, is, merely to expose the Person: and that of it self is Torture enough to a generous Mind. But the Populace think the Sentence too favourable; nor must the unhappy Creature exalted to that vile Eminence, hope to escape their Severities. In short, there are some Instances where the Criminal has dy'd on the spot, being bruised and wounded from Head to Foot, poison'd with stench, and stifled with an insupportable Load of Filth. Law indeed is suppos'd to be founded on Reason and Equity, and to sit the Punishment to the Nature of the offence. But of what signification is that Sentence, which dooms to the Whip, if the 
Criminal must be torn with Scorpions? which dooms to meer Exposition, if Wounds and Death must be the Consequence. For God's sake, let the Malefactor die at once, if his crimes be capital, and not have Reason to reproach those Laws, which have been notedfor Mercy to the vilest offenders. [Broderick (1731) 57]

Broderick protested his innocence throughout his tract, and therefore it is unsurprising that the account lacks a reflexive element of guilt or vulnerability. It is difficult to see that those interested in engaging in sodomitical activity would not see these issues in a more personal and threatening light.

In the population more broadly, the pillory had a role in transforming the public perception of sodomitical activity. Trumbach and Simpson are at one with associating the public sentiment against sodomites with a fear of effeminacy, both in the family settings of the lower classes and in the élite. Whatever the merits of this argument, and as Trumbach himself acknowledges, [Trumbach (1989) 408] the fine points of these distinctions are lost in the crowd setting. There is no obvious distinction between how consenting adults, paedophiles, and the more effeminate mollies were treated in the pillory. Thus of the cases referred to above, the long discussion of the pillorying concerned Vere street, a molly house case; Broderick was a case of alleged sexual activity with children; and Blair, the man who died, a case of consentual activity with Thomas Deacon, another adult pilloried also. This last is interesting, in that both seemed to have been used equally harshly by the crowd. There is no distinction drawn between penetrating and penetrated partners. Blair's death was attributed by commentators to flow from his weaker constitution, not a different treatment by the crowd. The crowd seems not to have acknowledged the three classes noted above as different for purposes of treatment in the pillory. 
A point of connection should be noted here with David Rollinson's discussion of the case of George Andrews, a tenant farmer, in Gloucestershire in 1716. [Rollinson (1981)] Andrews was alleged to have sodomized Walter Lingsey, a servant in husbandry. The allegation of Lingsey contained no molly overtones; it was a simple seduction between adults, occurring first on a bridge, then over beer in Andrews' cellar, and continuing in bed. The crowd enacted a "mock groaning", a symbolic re-enactment of the event. The crowd's version translated the event into an effeminate universe. Lingsey was portrayed dressed as a woman, and an entire birthing scene was enacted by the crowd. The imposition of this imagery already suggests the impact of the molly subculture on the public understanding of sodomitical acts. Already, this provides evidence of a new and unified characterization of sodomy on gendered lines.

The mock groaning is a particularly clear example of such a new and gendered conception. The uniform treatment of sodomites at the London pillory suggests a similar blurring effect, however, and a creation of a unified category of sodomite, subject to public condemnation.

\section{Conclusion}

The object of this essay has been to problematize the relationship between the pillory as an institution and the crowd attitude to the sodomitical behaviour of the people held within its jaws. The pillory was a space where, subject to minimal controls, the crowd held sway. The pillory therefore was a site for this crowd to articulate its values and norms. The events were frequently reported, and while the events themselves may say as much about the institution as the crime, the reports nevertheless may be taken as having an effect on the public perception of sodomitical activity. The 
pilloryings were public and notorious. As such, they are more likely to have constructed, rather than merely reflected, the emerging public understanding of sexual behaviour of men.

The accounts of sodomites in the pillory mythologize their experience, re-creating it and investing the behaviour of the crowd with a public meaning. It is no longer just an angry crowd, but a meaningful event. Rather than merely reflecting social attitudes, the reports of the aggressive usage by the crowd were a part of the symbolic erection of sodomy in the eighteenth century. 


\section{References}

Anon. (1759) Memoirs of the Pillory; being a Consolitory

Epistle to Dr. Shebbeare, 2nd ed. London: Cabe.

Anon (1822) "A Correct Account of the Horrible Occurrence Which took place at a Public-house in st. James' Market, in which it was discovered that The Right Rev. Father in God the Bishop of clogher, lately transferred from the Bishopric of Ferns, was a principal actor with a Common soldier! To the disgrace not only of the Cloth, to which he as attached, and as a Commissioner of the Board of Education, and a Dictator of Public Morals, but as a Member of that Nation which gave him Birth!" London: J.L. Marks.

Anon. (n.d., 1828?) "Final Commitment of Allison, for a Detestable Crime". London: Birt, n.d.

Beattie, John (1985) "Violence and Society in Early-Modern England". In A. Doob and E. Greenspan, Perspectives in Criminal Law. Toronto: Canada Law Book, 36-60.

Bingham, Caroline (1971) "Seventeenth-Century Attutudes towards Deviant Sex", Journal of Interdisciplinary History 1:446-472.

Bohstedt, John (1988) "Gender, Household and Community Politics: Women in English Riots 1790-1810", Past and Present $120: 88-122$.

Bray, Alan (1982) Homosexuality in Renaissance England. London: Gay Men's Press.

Broderick, Isaac (1731) An Appeal to the Public, or the Case of Mr. Isaac Broderick, Late of Trinity College Cambridge, Fairly and Impartially Stated. London (?) : privately published. 
Cady, Joseph (1992) "'Masculine Love', Renaissance Writing, and the 'New Invention' of Homosexuality", Journal of Homosexuality $21: 9-40$.

$\underline{\text { Fogg's Weekly Journal }}$

Forster Thomas (1656) The Lay-Man's Lawyer, 2nd ed. London: Twyford.

Foucault, Michel (1978) The History of Sexuality, Volume I: An Introduction. New York: Random House.

Gentleman's Magazine.

Gilbert, Arthur N. (1977) "Sexual Deviance and Disaster in the Napoleonic Wars", Albion 98-114.

Gilbert, Arthur N. (1978) "Sodomy and the Law in Eighteenthand Early Nineteenth-Century Britain", Societas 8:225-241.

Greenberg, David. (1988) The Construction of Homosexuality. Chicago: University of Chicago Press.

Hare, Francis (1731) "A Sermon Preached to the Societies for Reformation of Manners at St. Mary-le-Bow on Tuesday January the 5th, 1730". London: Downing.

Harrison, Mark (1986) "The Ordering of the Urban Environment: Time, Work, and the Occurrence of Crowds 1790-1835", Past and Present 110: 134-68.

Harvey, A.D. (1978) "Prosecutions for Sodomy in England at the Beginning of the Nineteenth Century", Historical Journal 21 : 939-948. 
Hay, Douglas and Francis Snyder (1989) "Using the Criminal Law, 1750-1850: Policing, Private Prosecution, and the state", pp. 3-52 in Hay and Snyder (eds), Policing and Prosecution in Britain 1750-1850. Oxford: Clarendon.

Hill, Brigit (1989) Women's Work and Sexual Politics in Eighteenth Century England Oxford: Blackwell's.

Holloway, Robert (1813) The Phoenix of Sodom, or the Vere Street Coterie. London.

King, Peter (1989) "Prosecution Associations and Their Impact in Eighteenth-Century Essex", pp. 171-207 in Hay and Snyder (eds), Policing and Prosecution in Britain 1750-1850. Oxford: Clarendon.

McIntosh, Mary (1968) "The Homosexual Role", Social Problems 16: $182-92$.

McLynn, Frank (1989) Crime and Punishment in Eighteenthcentury England. London: Routledge.

Moran, Leslie (1996) The Homosexual(ity) of Law. London: Routledge.

Norton, Rictor (1992) Mother Clap's Molly House: The Gay Subculture in england 1700-1830 London: Gay Men's Press.

Old Bailey Sessions Papers.

Rudé, George (1964/1995) The Crowd in History. London: Serif.

Philips, David (1989) "Good men to Associate and Bad Men to Conspire: Associations for the Prosecution of Felons in England 1760-1860", in Hay and Snyder, Policing and Prosecution in Britain 1750-1850. Oxford: Clarendon. 
Rolliston, David (1981) "Property, Ideology and Popular Culture in a Gloucestershire Village 1660-1740" Past and Present 93: $70-97$.

Simpson, Antony E. (1984) "Masculinity and Control: the Prosecution of Sex Offences in Eighteenth-Century London". Unp. doctoral dissertation, New York University.

Smith, Greg (1996) "Civilized People Don't Want to see That Kind of Thing: The Decline of Public Physical Punishment in London, 1770-1840" in Qualities of Mercy: Justice, Punishment and Discretion, ed. Carolyn Strange. Vancouver: University of British Columbia Press.

Thompson, E.P. (1971) "The Moral Economy of the English Crowd in the Eighteenth Century" Past and Present 50: 76-136.

The Times Newspaper.

Trumbach, Randolph (1976) "London's Sodomites: Homosexual Behavior and Western Culture in the Eighteenth Century" Journal of Social History 11: 1-33.

Trumbach, Randolph (1985) "Sodomitical Subcultures, Sodomitical Roles, and the Gender Revolution of the Eighteenth Century: The Recent Historiography" Eighteenth Century Life 9: $109-121$.

Trumbach, Randolph (1989) "Sodomitical Assaults, Gender Role, and Sexual Development in Eighteenth-Century London",

Trumbach, Randolph (1990) "Sodomy Transformed: Aristocratic Libertinage, Public Reputation and the Gender Revolution of the 18th Century", Journal of Homosexuality 19: 105-124. 
Weeks, Jeffrey (1989) Sex, Politics and Society: The Regulation of Sexuality since 1800. 2nd ed. London: Longman's.

Wynn, John (1726) "A Sermon preached to the Societies for the Reformation of Manners, at St. Mary-le-Bow, on Monday January the 3d, 1725." London: Downing. 
i. The existence of such a sodomite subculture prior to this time is more controversial. See Bray (1982), Trumbach (1985), Cady (1992) and the sources cited therein for arguments relating to such a subculture in renaissance England.

ii.This term is used with some hesitation, since it is so clearly anachronistic. At the same time, there is no obvious less-jarring alternative to convey the required meaning of public spaces used to locate sexual contacts, for activity which might occur either on the site, or at a place removed.

iii.There were three cases at the Old Bailey in the between 1716 and 1790: Wales (July 1757), Aynsworth (September 1779) and Wright (1787). Only Wales was convicted. At the Middlesex sessions, I have found three such cases on the calendar of indictments between 1715 and 1775: Burn (June, 1735), Packman (July 1765) and Strongate (April 1772). This source does not indicate the outcome of any of these three cases.

iv. See Hawkins, Pleas of the Crown, 2nd ed (1724) at 6. A different view had been taken by Chief Justice Hyde in Castlehaven's case (1631) that emission only needed to be proven. Cf. 9 George IV (1828) c. 31, s. 18, which altered the rule so that penetration only needed to be proven.

Thile the pillory remained a common punishment throughout the century for perjurers and, most interesting in the context of this paper, those convicted of extortion by threat of a charge of sodomy, it would appear to have been less common in between roughly 1750 and 1790 within London, for those involved in sodomitical practices. It was still a reasonably common punishment for such offences outside Middlesex County, and was revivied in Middlesex well before the turn of the century.

vi. See Broderick (1731) regarding prosecutors organizing and inciting crowds at the pillory in this fashion. My thanks to Doug Hay for alerting me to the likelihood that state officers might be similarly active.

vii.Other references to the aggressors at the pillory of sodomites being composed primarily of women may be found, for example, in The Times, 2 March 1795 3c and 9 October 1802 3a. In 1698, the theme is picked up in "The Women's Complaint to Venus", a pamphlet distributed at the pillorying of Edward Rigby for attempted sodomy, quoted at Norton (1992) 46.

viii.For other similar ballads not specifically related to the pillory, see Greenberg (1988) 335-6; Norton (1992).

ix.For a considerably more nuanced discussion of these and other figures, see Trumbach (1990).

x.My search of the calendar of indictments for the Middlesex Sessions, now kept at the Greater London Record Office, has turned up 119 charges for activity between men between 1715 and 1775. Of these, 25 were found ignoramus, and therefore did not proceed. Certiorari issued from King's Bench in an additional 11 cases. I am unclear of the outcome of 58 cases. Of the remaining 25, there were 13 acquittals and 12 convictions. This is consistent 
with the views of the other historians in the field. Gilbert, for example, notes only six attempt charges in London and Middlesex from 1805 to 1809 inclusive, and claims that this represents a marked increase in prosecutions from earlier periods. [Gilbert (1977) 98-103]

xi.For this reason, it is perhaps unwise given the very small number of cases to place too much significance on the variations in frequency of cases prosecuted over the century, as a marker of broad social attitudes. Thus Trumbach [ (1985) 113] is on unsafe ground when he criticises Simpson's chronology regarding the articulation of the new masculinity on the basis of an increase in the number of cases in the 1720s. In absolute terms, the number of cases remained very small. The increase is more appropriately explained by the interest of the Society for the Reformation of Manners in prosecuting sodomy-related offences in this period. The issue of social perceptions must thus centre on the significance and representativeness of the Society, not the blip in the case law. 